\title{
GOVERNMENT'S PERFORMANCE ON THE PUBLIC SERVICE REGARDING BUILDING PERMITS IN URBAN PLANNING OFFICE OF GORONTALO CITY
}

\author{
Ismet Sulila $^{1^{*}}$, Tineke Wolok ${ }^{2}$ \\ ${ }^{\text {I}}$ Study Program of Public Administration, Faculty of Economics, Universitas Negeri Gorontalo, Gorontalo, \\ Indonesia \\ ${ }^{2}$ Study Program of Management, Faculty of Economics, Universitas Negeri Gorontalo Gorontalo, Indonesia \\ *Corresponding Author: ismet.sulila@gmail.com
}

\begin{abstract}
Government's performance in the public service regarding building permit in Urban Planning Department of Gorontalo City. This research aims at investigating the public service performance at the Urban Planning Office of Gorontalo city. This qualitative descriptive research employed observation, interview, and documentation in collecting the data. The technique of data analysis comprised of data reduction, data display, and conclusion. The results reveal that the government's performance is influenced by 1) human resources, 2) facilities and infrastructures, and 3) job mechanism. Furthermore, the efforts to improve the performance are 1) participation of the officers in technical training about building permits policy; 2) disseminating the insight regarding building permit on the district level through the media such as newspaper, television, and radio; 3) providing proper facilities and infrastructures. Efforts to improve the performance should include 1) upgrading human resources; 2) providing facilities and infrastructures; 3) coordinating with the local government unit; 4) promoting awareness of the society since some people do not have a properunderstanding of the legality of building permits.
\end{abstract}

Keywords: Performance and Public Services

\section{INTRODUCTION}

The recent national development process has been shifted from the authoritarian-based to democratic system. This leads to critics on several aspects of governance, particularly accountability, efficiency, and effectiveness. In such a context, the principles of good governance in the management of the government become the priority since people are more critical to monitor and evaluate benefits and values from the public services of the government. On the other hand, measuring the success and failure of the government services in carrying out their duties based on their roles through objective approach is intricating. This blames the absence of the implementation of performance measurement by which the results are able to inform the success rate of the conduct of the government services and its programme.

The provision of public services by the state officers is the embodiment and the roles of these officers to help the people in addition to their primary duty to serve the country. By that, it goes without saying that community acts as the pioneer of their nation's development while the government is responsible for guiding and promoting a situation to support their people. State officers are obliged to be able to improve their performance, formulating a concept, as well as promote a conducive atmosphere where the people are independent and wealthy.

Landscape and Urban Planning Office of Gorontalo city, as among the public services, also concerns with the issue of the accomplishment of an organization. Issuing the building permit is among the responsibilities of this institution. The data from this organization regarding the building permit issuance in the last three years reveal that the percentage of the service accomplished is $72 \%$ in 2013, 68\% in 2014, and 66\% in 2015. These reveal that the issuing of the building permit is not that effective in the recent years.

The problems explained in the above discussion draws the researcher's interest to explore such an issue in a study entitled "Government's Performance in Issuing Building Permit on the Landscape and Urban Planning Office of Gorontalo City". This study focuses on 1) the government's performance in the conduct of building permit issuance on the Landscape and Urban Planning Office of Gorontalo City, and 2) exploring the efforts that must be attempted by the Landscape and Urban Planning office to enhance the work of bureaucratic apparatus in the issuance of building permit. 


\section{RESEARCH METHODOLOGY}

A descriptive qualitative approach was applied to explore the way the organizationestablish the building permits as well as the efforts to improve the service further. This study was conducted in Gorontalo city since the issue becomes the foremost concern of this area. This study was conducted for three months.

Primary and secondary data, which obtained through methods, e.g., observation, interview, and documentation, were comprised in this study. These were further analyzed descriptively to get a better description of a number of social situations in which such a condition leads to a rise in the number of the issue of child abuse in Gorontalo city. This is also to find out a social dimension to address such a problem. Miles, Huberman, and Saldana (2014) state that there are three processes conducted at the same time in qualitative analysis, which are namely data condensation, data display and conclusion drawing/verifications.

\section{FINDINGS AND DISCUSSION}

This section provides the research findings focused on the two problems of this study.

1. The government's performance in the conduct of building permits issuance on the Landscape and Urban Planning Office of Gorontalo City.

\section{a) Input}

The aspect of input in the implementation of government programmes is essential. In the present study, this aspect is associated with the resources in an organizational unit which involves human resources, facilities, and infrastructure, as well as the work procedures of the issuance of building permit. These three indicators are explained separately in the following sections.

\section{1) Human Resources}

Competent human resources are essential in the conduct of the issuance of building permit. Bastian (2001) argues that the level of the achievement of a job to meet the target, purpose, as well as the vision and mission of an organization requires skilled workers. In other words, human resources determine the success of a public service. Relating to this, one of the informants reported that one office is dealing with the building permit issuing attempts to enhance the workers' insight through reviewing the rules once in six months despite the limited human resources. This is to speed up the problem-solving procedures since the issue regarding the permit issuance is complex. Such a report confirms that human resources affect the realization of the issuance of building permit. Furthermore, this informant reveals that the officers in the Landscape and Urban Planning Office of Gorontalo city, especially those whose responsible deal with the drawings and measurement job, which are less in its number, find it difficult to carry out their job since their working areas consist of nine districts. The job descriptions of these workers also range from image processing to the issuance of Advice Planning of building permit. With a team of only 12 members, it is hard to imagine how these officers work to survey the buildings in nine districts in Gorontalo city.

The lack of the awareness of the society regarding the building permit has also worsened the situation. People mostly assume that having building permit is only about prestige rather than abiding the government's rule. It should be noticed that the issuance of such a permit aims to manage a city, especially Gorontalo city. The informant also reveals that the officers are having a double-duty-they deal with their work based on the job description and observe the site at the same time. Regarding the information of human resources, it is revealed that the officers of the regional government agency handle two jobs in different fields, which are Site Planning and Building Control division. Each field consists of three sections with a number of staffs. The job of these fields is correlated with each other in which the conduct starts from the Site Planning to the Building Control division.

It can be inferred that the issuance of a building permit by the Landscape and Urban Planning office of Gorontalo is without question a complicated process through a long process. Furthermore, the informant, which happens to be the head of the Site Planning division emphasizes that the job of the staffs revolve around the building planning, mapping, and measurement. If the requirement has been fulfilled, the division of Building Supervision will continue the work. This informant also states that only $60 \%$ of the staffs are technically qualified since the rests, who are usually not involved in the process of building permit, also takes part in the conduct of the issuance. This blames the total workers on the staff which also leads to the duration of the permit issuance. Processing the issuance usually takes two to three days, but due to the issue, the application process might be finished in six days.

All in all, the procedures of building permit issuance requireexperienced officers with sufficient understanding regarding the concept of building technique. This is in line with the concern of the informant that the competent human resources of Urban Planning office of Gorontalo city are lack in its number by which affect the procedure of the issuance. 


\section{2) Facilities and infrastructures}

The lack of facilities and infrastructures impact on the performance of the human resources-which refer to the officers in this issue. This is in line with the statement of the informant, the head of the site planning division, about the facilities that are still unavailable to conduct their work. For example, the measurement process is mostly manual despite that the use of a modern measuring tool, i.e., an infrared measurement device, has been widely used nowadays. Furthermore, devices for aerial photography are also yet to be used. These tools are helpful to view a particular area from above. Currently, regarding the photographic works, the office mostly rely on standard computers which results in low-quality images. On top of that, another informant from the division of supervision reports that vehicles for the official purposes are also needed to facilitate the team to get to the work site.

By these explanations, it is confirmed that the facilities and infrastructures in the site planning and control office are unable to support the conduct of their works, yet people demanda good service in the issuance of building permit. In addition, it is suggested to maximise the supporting facilities or at least to find out other alternatives to cope with possible issues which results in a better public service.

Another issue relating to the above discussion is the lack of filing cabinet for storing the archives of the office. The increase of the documents to be archived is inevitable from time to time. If there are five documents in each day, the whole documents will be 60 in only a month. Cabinets for storing these files are required, yet the facilities are limited.

This informs that all the sections, including the division of supervision as the survey officers, in the office are in demand of supporting facilities. In conclusion, the improvement on these aspects is able to enhance and maximise the work of the officers.

\section{3) Procedures for permit issuance}

It is revealed that the Urban Planning Office should have its standard procedures for the client; this ranges from the registration and application submission, inspection request, document verification, to informing the clients. The application will be submitted to the licensing division once the application is complete, otherwise, it will be returned to the applicant for completion. The soon the applicant complete the application, the sooner the licensing officers receive the documents. In other words, people who argue that the service of the urban planning division should consider twice prior to complaining since they are also a contributing factor to such an issue. This also confirms that the procedures are clearly stated, yet it does not ensure the effectiveness of the service due to some possible issues. The problems might be from the office of related stakeholders, applicants, or other factors, e.g., weather condition which may obstruct the field survey.

\section{b) Process}

Another focus of the first problem, in addition to the variable of performance, is the aspect of the process. This aspect refers to the conduct of the services which also leads to the performance of the officers. The results of the field study reveal that officers, in terms of the aspect of the process, are able to provide the service regarding the building permit issuance. It is also reported that the capability of the officers of the site planning division and the way the clients fulfill the documents required are the contributing factor of the verification of the document. The officer's capability is about the thoroughness in verifying a document. The competence of the officers of the division of supervision focuses on how they are able to ensure aspects of the building, such as feasibility, security, as well as the border between two buildings. In other words, experienced officers will be less likely to have an issue in handling their duty since they already understand the procedures. On the other hand, the mutation of employee signifies that the officers need more time to adapt to the job to lessen the issue during the working. Workers in the division of supervision can conduct their work. However, this is not a guarantee for the effectiveness of the field survey because of such a job associates with other institutions or offices.

Preceding the above variable is facilities and infrastructure. Supporting facilities and infrastructures are also important for the officers. Competent employees require these to improve their work further. This is in line with the data of the licensing control division that the facilities are still in need despite that workercan accomplish their work. Nevertheless, this might impact on their performance. Some examples of the issues regarding facilities and infrastructures are a blackout, unavailability of the generator which obstructs the working progress. Even the data input is complete; more documents are to be archived while the storage is still unavailable. Which affects the service of the office.

Similarly, such an issue also persists in the control office. It is reported that the workers find it difficult to get to the working site since vehicles are still required. In conclusion, workers' capability and supporting facilities are inseparable because these aspects influence the performance. The capability of the officers in the 
process of the issuance of the permit is also included in this variable. The data of the site planning office report that all the issuance service have been verified.There have been any issues in the conduct of the permit establishment, yet people are lack of the information regarding the document verification procedures. The procedures clearlystate the duration for verifying the document prior to continuing to the further step in the control office.

c) Output

Officers are the contributing factor in the quality of government's performance. The example of this study is how the officers of the Public Park and Urban Planning office of Gorontalo city process the issuance of building permit. Public services refer to government's service subject to the people's demand whose grounding is the procedures and the codes of conduct that have been established. People will consider that the service is good if it meets their needs and expectation. According to the Public Park and Urban Planning office, an improvement on the issuance of a building permit is necessary considering the expectation of the people. The services of the Public Park and Urban Planning office of Gorontalo city are peoples satisfaction oriented. These are based on the vision, mission, motto, and commitment of the body to serve the public with speed and quality licensing services to fulfill their needs.

The data of the division of licensing supervision reveal that the services are of good quality. However, the lack of people's understanding regarding the process of building permit issuance leads to a paradigm that registering their building to the office is time-consuming. In addition, the division of licensing supervision licensing reveal that issues of facilities and infrastructure, such as cars, obstruct the work of the employees to supervise the building in their working site. The society also does not understand that some issues obstruct the work of the Site Planning division by which require skilled and competent human resources.

In conclusion, workers' capability and supporting facilities are inseparable because these aspects influence the public service providers. Disseminating the insight regarding issuance is necessary to shape people's perspective and improve their understanding of the process and problems of building permit as well. This is echoing the results seen in Parasuraman, Zeithaml, and Berry (as cited in Tjiptono, 2008) that a quality service is if the requirements have been met in its practice. People's expectation is also included in among the lists of the requirement.

\section{d) Outcome}

The quality of the building permit officers in their practice contributes to the administrative assurances of building ownership. In other words, the officers must be able to deal with issues of building permit issuance to improve the government and promote people's wealth through quality public services. The head of the Public Park and Urban Planning office of Gorontalo city explains that the provision of public services, i.e., the issuance of building permit, grounds on the general principles of good governance. The conceptualization of such principles is somewhat difficult since laws that constitute the conduct havebeen yet established. On the other hand, the ideas of good governance should also be considered in the process of the issuance of building permit in Gorontalo city. Furthermore, the conduct of the issuance in Gorontalo is based on the General Principles of a Good Governance to provide the people with the assurance of the Building Ownership and further promote welfare as well. Such insurance represents that the building permit gives the owner the legal protection which is expected to contribute to the people in Gorontalo city positively.

\section{Efforts of Public Park and Urban Planning office in enhancing the work of bureaucratic apparatus in the issuance of building permit.}

a) Human Resources

Focusing on the capability and skill of the officers is among the efforts to improve the building permit service. This is because officers are urged to be professional during their work as the pioneer in providing the people with quality public services. In addition, the placement of the officers in a particular working site should consider the needs of the public service to improve the conduct based on the procedures. It is revealed that the officers of the regional government agency handle two jobs with two divisions handling the work focused on the Site Planning and Building Control. Each consists of three divisions with a number of staffs. The main duty of these fields is correlated with each other in which the conduct starts from the Site Planning to the Building Control division. The services are available every day depending on the demand of the society who wants to apply for a permit. On the other hand, the demand of the people demands the total staffs signified by the complaints regarding the service. Therefore, recruiting more officers is necessary to boost the performance and maximise the service of building permit issuance. The institution has already provided the quality services and having more employees will further improve the conduct. 


\section{b) Facilities and infrastructures.}

Facilities and infrastructures are essential to support the government, including the Public Park and Urban Planning Office. These should suit the needs of the conducts of the service, e.g., tools and workplace, to promote a good working atmosphere-resulting in time and cost efficiency. Otherwise, the lack of supporting facilities and infrastructures obstruct the work of an institution, for example, Public Park and Urban Planning office of Gorontalo city. It can be inferred that adding more facilities, such as transportation for the employees, is important for this institution to serve the people with satisfying public services and accomplish the conduct of the duty. Since these aspects are necessary, the institution shall submit requests for the facilities.

\section{c) Procedure}

Re-structuring the procedures of the conduct is without question an obligation for state officers. Similarly, Said (2007) argues that the characteristic of bureaucracy is the presence a hierarchical and detailed job description the rules. A Clear description of working mechanics and procedures are crucial in the process of an effective and efficient public service. Thereby, the working mechanism and procedures must be designed thoroughly to avoid errors. Determining the feasibility of the mechanism of the procedure is the accomplishment of the service. If the outcome does not satisfy the target, ones should identify the fault in designing the procedure. Based on the results of the study, continuous improvement on the mechanism and procedures of the service can boost the performance of the public service represented by the high satisfaction rate of the society. By that, the government of Gorontalo proposes some approaches to improve the issuance of a building permit as depicted in the following chart.

3. Efforts of Public Park and Urban Planning office in enhancing the work of bureaucratic apparatus in the issuance of building permit.

\section{a) Human Resources}

Focusing on the capability and skill of the officers is among the efforts to improve the building permit service. This is because officers are urged to be professional during their work as the pioneer in providing the people with quality public services. In addition, the placement of the officers in a particular working site should consider the needs of the public service to improve the conduct based on the procedures. It is revealed that the officers of the regional government agency handle two jobs with two divisions handling the work focused on the Site Planning and Building Control. Each consists of three divisions with a number of staffs. The main duty of these fields is correlated with each other in which the conduct starts from the Site Planning to the Building Control division. The services are available every day depending on the demand of the society who wants to apply for a permit. On the other hand, the demand of the people demands the total staffs signified by the complaints regarding the service. Therefore, recruiting more officers is necessary to boost the performance and maximise the service of building permit issuance. The institution has already provided the quality services and having more employees will further improve the conduct.

b) Facilities and infrastructures.

Facilities and infrastructures are essential to support the government, including the Public Park and Urban Planning Office. These should suit the needs of the conducts of the service, e.g., tools and workplace, to promote a good working atmosphere-resulting in time and cost efficiency. Otherwise, the lack of supporting facilities and infrastructures obstruct the work of an institution, for example, Public Park and Urban Planning office of Gorontalo city. It can be inferred that adding more facilities, such as transportation for the employees, is important for this institution to serve the people with satisfying public services and accomplish the conduct of the duty. Since these aspects are necessary, the institution shall submit requests for the facilities.

c) Procedure

Re-structuring the procedures of the conduct is without question an obligation for state officers. Similarly, Said (2007) argues that the characteristic of bureaucracy is the presence a hierarchical and detailed job description the rules. A Clear description of working mechanics and procedures are crucial in the process of an effective and efficient public service. Thereby, the working mechanism and procedures must be designed thoroughly to avoid errors. Determining the feasibility of the mechanism of the procedure is the accomplishment of the service. If the outcome does not satisfy the target, ones should identify the fault in designing the procedure. Based on the results of the study, continuous improvement on the mechanism and procedures of the service can boost the performance of the public service represented by the high satisfaction rate of the society. By that, the government of Gorontalo proposes some approaches to improve the issuance of a building permit as depicted in the following chart. 


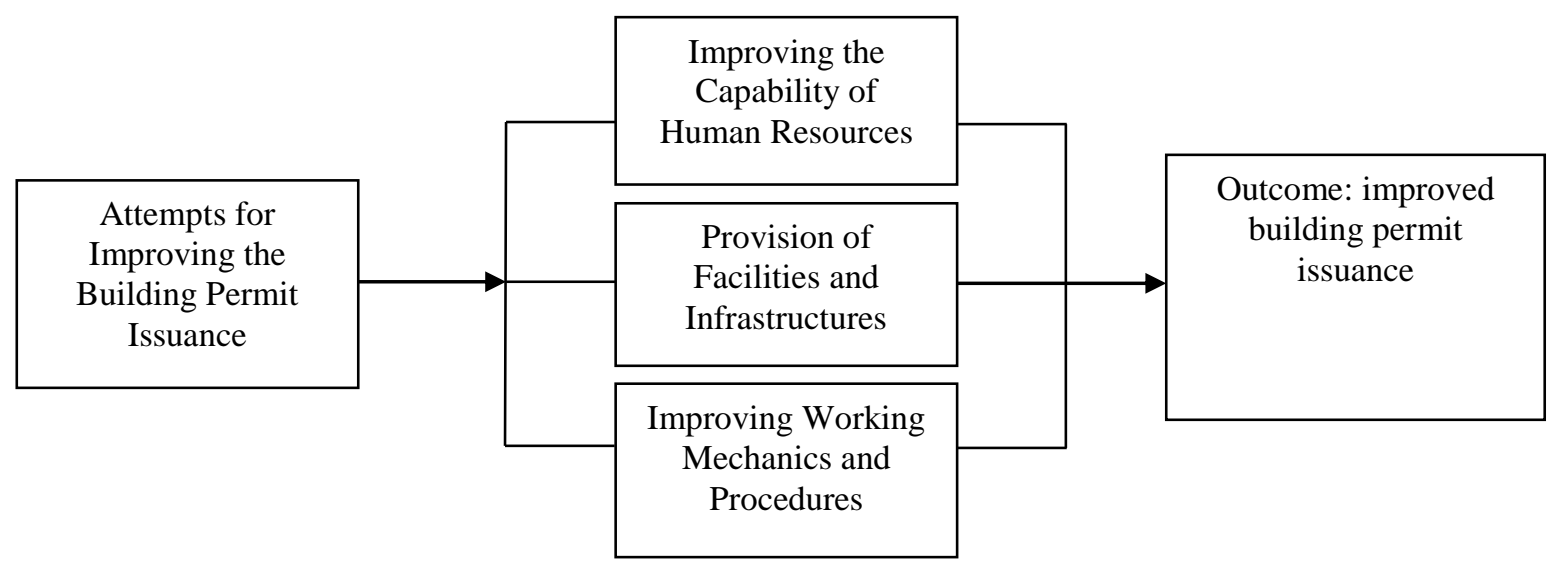

Figure 1. Efforts for Improving the Performance of Building Permit Issuance in Gorontalo City

\section{ANALYSIS}

It is shown that the Public Park and Urban Planning office of Gorontalo City has yet to provide quality public services. This is indicated by aspects, e.g., a limited number of state officers, facilities, and infrastructure, lack of service procedures, as well as the accomplishment rates which lead to the urgency for the office to address issues regarding these indicators. This is in line with the Decree of Ministry of Empowerment of State Apparatus and Bureaucracy Reform Number 63/KEP/M.PAN/2003 of general guideline of the conduct of public services that urged every public service institutions to pay attention to the principles of the services in its practice. Therefore, the performance of the Public Park and Urban Planning office does not meet the people's expectation. The services of the Public Park and Urban Planning office of Gorontalo city are peoples satisfaction oriented. These are identified by the vision, mission, motto, and commitment of the body to serve the public with speed and quality licensing services to fulfill the needs of the society. This is in line with the results seen in Tjiptono (2008) that a quality service is if the requirements have been met in its practice. People's expectation regarding the service is also included in among the lists of the requirement. Assessing the organization's performance is crucial to identify the success, the accomplishment, and the extent of the work of the organization. This is in line with the statement seen in Dwiyanto (2002).

The results of interview and field observation reveal aspects, such as input, process, and output are significant to enhance the government's attempt at providing public services.

\section{a. Input}

Improvement in some areas in Public Park and Urban Planning Service of Gorontalo city, especially the conduct of the service, is inevitable. This blames aspects, such as inexperienced workers and lack of supporting facilities. Although the office is equipped with sophisticated media to help the conduct of the work, human resources become the foremost concern of an institution. This is because they contribute to the success of an organization. Theoretically, one's competence is based on the ability to master technology and able to utilize facilities during working. Therefore, it is difficult for an organization to achieve their target with only being equipped with modern technology which implies the necessity to improve the quality of the workers.

\section{b. Working Process}

In terms of the mechanism, the building permit issuance covers an easy service procedure and more simplified requirements. In addition, the availability of information and complaints counters as the media to receive people's suggestions and criticism may imply that the Public Park and Urban Planning Office in Gorontalo city is giving more priorities to the customers' interests, needs and expectations rather than the organization's, individual's or bureaucracy's interests. However, in terms of the settlement time, the Public Park and Urban Planning Office in Gorontalo city has not been able to finish it in accordance with the requested time and existing regulations. This is due to the obstacles that occur in the administrative and technical aspect. Therefore, the procedure is a fixed pattern of the organizational activities series. Understanding the series can be assumed as the stages of doing work or can be simply regarded as the level of management. This is in line with State Administration Institution (1994) that a series of working procedures are related to each other so that it shows a clear sequence of stages and the ways that must be takenin order to accomplish a task.

\section{c. Output}

The quality of building permit services in the Public Park and Urban Planning Office in Gorontalo city has not reached the good category. Thisis caused by the provided service that has not met the customers' expectations and satisfaction. Thisis based on the results of interviews and observations on direct evidence of the office requirements, 
computerized administration, the measuring instruments is not adequate in which adequate facilities and infrastructures are required to support the services. Similarly, Moenir (1995) states that facilities are all types of equipment, work equipment and other facilities functioning as the maintool/assistant in finishing a work along with the social function in terms of the interests of people who are associated with the work organization.

In addition, the technical and non-technical ability of the employees in the Public Park and Urban Planning Office in Gorontalo should be improved. Thisis in compliance with Moekijat (1986) who notes that the education and training of the civil servants are including 1) improving the ability in order to accomplish the work quickly and accurately, 2) improving knowledge in order that the work can be finished nationally, 3) cooperating with colleagues and leaders.

\section{CONCLUSIONS}

The conclusions of this present study are as follows:

1. There are several contributing factors of the government's performance in the conduct of building permit issuance on the Landscape and Urban Planning Office of Gorontalo City. These are a) human resources; b) facilities and infrastructure; and c) working procedures. 2. The efforts that must be attempted by the Landscape and Urban Planning office to enhance the work of bureaucratic apparatus in the issuance of building permit involve 1) improving the quality of human resources and recruiting more employees; 2) disseminating the information regarding the issuance of building permit through media, e.g., newspaper, television, and radio; 3 ) providing supporting facilities and infrastructures.

This study formulates several recommendations as follows: 1) Improving the capability of the workers of Public Park and Urban Planning office of Gorontalo city, especially in the issuance of building permit, is necessary. 2) The institution should provide supporting facilities, e.g., modern measurement tool, aerial camera, and transportation since this aspect shapes the perception of the society. 3) One-stop Permit Services Board and Regional Government Agency should cooperate to establish a standard to speed up the process of public services. 4) Promoting workshops in every district is also beneficial because most people lack understanding about the importance of the legality of a building permit.

\section{REFERENCES}

Bastian, I. 2001. Akuntansi Sektor Publik, ed.1 [Public Sector Accounting, $1^{\text {st }}$ Edition], Yogyakarta: Badan Penerbit FE UGM.

Dwiyanto, A. 2002. Reformasi Birokrasi Indonesia, Pusat Studi Kependudukan dan Kebijakan [Bureaucratic Reform of Indonesia, Center for Population and Policy Studies], Yogyakarta.

Tjiptono, F. 2008. Strategi Pemasaran, Edisi 3 [Marketing Strategy, $3^{\text {rd }}$ Edition], Yogyakarta.

Moenir, H.A.S. 1995. Manajemen Pelayanan Umum di Indonesia [Public Service Management in Indonesia], PT Bumi Aksara.

Lembaga Administrasi Negara, 1994.

Said, M. 2007. Birokrasi di Negara Biroktasis [Bureaucracy in Biroktasis State], Malang: UMM Press.

Miles, M. B. A., Huberman, M., Saldana, J. 2014. Qualitative Data Analysis: A methods sourcebook, Third Edition, Sage Publication, Inc.

Moekijat, 1986, Sistem Informasi Manajemen [Management Information System], Bandung: Remaja Karya.

\section{Legal Resources}

Keputusan Menteri Pendayagunaan Aparatur Negara Nomor 81 Tahun 1993 yang kemudian disempurnakan dengan keputusan Menteri Pendayagunaan Aparatur Negara No. 63 Tahun 2003 [Decree of Ministry of Empowerment of State Apparatus and Beaurocracy Reform Number 81 of 1993 subsequently refined by Decree of Ministry of Empowerment of State Apparatus and Beaurocracy Reform Number 63 of 2003]. 